\title{
PENGOLAHAN DATA MANAJEMEN ASET KANTOR BAPPEDA PROVINSI RIAU DENGAN METODE STRAIGHT LINE DAN MULTI ATTRIBUTE UTILITY THEORY
}

\author{
Ade Putra, Hasanuddin, Syahril \\ Fakultas Ilmu Komputer Universitas Muhammadiyah Riau
}

\begin{abstract}
ABSTRAK - Berdasarkan pengolaan program dan kegiatan dilikungan pemerintahan untuk menunjang dalam rangka usaha peningkatan kerja dan kualitas dari pembangunan daerah diperlukan peningkatan keselarasan, antara pembangunan sektoral dan pembangunan daerah, khususnya dalam pembangunan daerah terdapat kesinambungan pembangunan mengelola aset berupa aset tetap atau berwujud yaitu aset yang mempunyai masa-masa manfaat yang lebih dari satu tahun seperti aset tanah, kendaraan, peralatan kantor dan alat pendukung lainnya, sehingga perlu adanya sistem yang dapat mencatat ataupun melakukan pendataan data aset, nilai aset, penyusutan aset dan penghapusan aset. Hal ini dilakukan agar dapat menentukan nilai aset, penyusutan aset dan nilai buku dengan metode straight line dan penerapan sistem pendukung keputusan kelompok dalam penghapusan aset yang dibuat menggunakan metode MAUT (Multi Attribute Utility Theory) dapat membantu para pengambil keputusan dalam melakukan perankingan nilai masing-masing alternatif solusi, sebagai pembobotannya dari setiap kriteria.
\end{abstract}

Kata kunci - Aset, Straight Line, Multi Attribute Utility Theory,

\section{Pendahuluan}

Pemanfaatan teknologi informasi computer dewasa ini semakin berkembang dan menjadi alat pengolahan data yang sangat penting di implementasikan dalam sebuah kegiatan baik kegiatan pemerintah, swasta, organisasi bahkan kegiatan perseorangan. Perkembangan tersebut dapat kita lihat pada setiap kantor atau usaha hampir semua telah menerapkan sistem informasi berbasis komputer. Pemanfaatan teknologi informasi komputer tersebut masih sangat terbatas dimana masih ada beberapa kegiatan yang rutin dilakukan secara manual. Setiap lembaga baik pemerintah, perusahaan, swasta, sekolah, organisasi atau badan yang lainnya dipastikan memiliki aset baik aset bergerak atau tidak bergerak yang harus dilakukan pengolahan data. Aset merupakan modal penting dalam menunjang kinerja atau kegiatan operasional, aset perlu dikelola, diidentifikasi, dirawat dengan baik sehingga dapat dipergunakan secara efesien dan efektif.

Sistem Informasi Manajemen Aset digunakan untuk pengelolaan aset atau inventori. Implementasi sistem informasi manajemen aset pada hakekatnya adalah upaya untuk tertib dokumen dan tertib administrasi pengelolaan aset. Tertib dokumen aset berkaitan dengan upaya penyediaan dan pendataan data-data atau dokumen yang menyertai keberadaan aset, sedangkan tertib administrasi lebih dimaksudkan pada upaya membangun prosedur pengelolaan aset mulai saat 
pengadaan, perubahan data, hingga penghapusan aset (Hartono, 2010).

\section{LANDASAN TEORI}

\section{a. Manajemen Aset}

Secara etimologis kata manajemen berasal dari bahasa Perancis Kuno ménagement, yang berarti seni melaksanakan dan mengatur. Sedangkan secara terminologis para pakar mendefinisikan manajemen secara beragam, diantaranya: Follet yang dikutip oleh (Wijayanti, 2008) mengartikan manajemen sebagai seni dalam menyelesaikan pekerjaan melalui orang lain. Menurut Stoner yang dikutip oleh (Wijayanti,(2008) manajemen adalah proses perencanaan, pengorganisasian, pengarahan, dan pengawasan usaha-usaha para anggota organisasi dan penggunaan sumber daya-sumber daya manusia organisasi lainnya agar mencapai tujuan organisasi yang telah ditetapkan.

\section{b. Penyusutan Aset}

Definisi penyusutan menurut PSAK No. 17 adalah alokasi jumlah suatu aktiva yang dapat disusutkan sepanjang masa manfaat yang diestimasi. Penyusutan untuk periode akuntansi dibebankan ke pendapatan baik secara langsung maupun tidak langsung. Aktiva yang dapat disusutkan adalah aktiva yang:

1. Diharapkan untuk digunakan selama lebih dari satu periode akuntansi.

2. Memiliki suatu masa manfaat yang terbatas.

3. Ditahan oleh suatu perusahaan untuk digunakan dalam produksi atau memasok barang dan jasa, untuk disewakan, atau untuk tujuan administrasi.

Aktiva yang dapat disusutkan seringkali merupakan bagian signifikan aktiva perusahaan. Penyusutan karenanya dapat berpengaruh secara signifikan dalam menentukan dan menyajikan posisi keuangan dan hasil usaha perusahaan.

Masa manfaat adalah:

1. Periode suatu aktiva diharapkan digunakan oleh perusahaan atau

2. Jumlah produksi atau unit serupa yang diharapkan diperoleh dari aktiva oleh perusahaan.

\section{c. Metode Straight Line}

Banyak metode penyusutan yang dapat digunakan. Sebenarnya entitas pelaporan diberi beberapa pilihan metode untuk penyusutan aset tetap Untuk Pemerintah Pusat, sesuai dengan PMK 01/PMK.06/2013 pasal 18 ayat 1 , metode penyusutan yang digunakan adalah metode garis lurus. Formula penghitungan penyusutan dengan metode garis lurus sesuai dengan lampiran PMK 01/PMK.06/2013 tersebut adalah :

1. Perhitungan dengan menggunakan nilai residu $=$

\section{(Harga Perolehan - Nilai Sisa/Residu)} umur ekonomis

2. Perhitungan tidak menggunakan nilai residu $=$

\section{Harga Perolehan umur ekonomis}

keterangan:

Umur ekonomis dihitung perbulan, karena beban penyusutan dihitung per bulan.

\section{Penyusutan per periode $=$ Nilai yang dapat diusutkan Masa manfaat/ umur ekonomis \\ Dengan rumus : $\mathbf{B p}=\frac{\mathbf{H p}}{\mathbf{T}}$}

Keterangan : 
$\mathrm{Bp}=$ beban penyusutan per periode

$\mathrm{Hp}=$ nilai yang dapat disusutkan

$\mathrm{T}=$ masa Manfaat/Umur ekonomis (Umur ekonomis dihitung pertahun, karena beban penyusutan dihitung per tahun.)

4. Nilai Buku $=$ Harga Perolehan - Nilai Penyusutan

\section{d. Multi Attribute Utility Theory (MAUT)}

Metode MAUT merupakan metode untukmembantu pengambilan keputusan. Secara ringkas, langkah-langkah yang dilakukan dalam metode MAUT dapat dituliskan sebagai berikut:

1. Pecahkan atau uraikan sebuah keputusan dalam dimensi yang berbeda.

2. Tentukan bobot relatif pada masingmasing dimensi.

3. Daftar semua alternatif yang ada.

4. Masukan nilai utilitas untuk masingmasing alternatif sesuai atributnya.

5. Kalikan nilai utilitas dengan bobot untuk menentukan nilai masingmasing alternatif.

Metode Multi Attribute Utility Theory digunakan untuk merubah dari beberapa kepentingan kedalam nilai numerik dengan skala $0-1$ dengan 0 mewakili pilihan terburuk dan 1 terbaik. Hal ini memungkinkan perbandingan langsung beragam ukuran. Yaitu, dengan alat yang tepat, itu memungkinkan saja untuk membandingkan apel dengan jeruk. Hasil akhirnya adalah urutan peringkat dari evaluasi alternatif yang menggambarkan pilihan dari para pembuat keputusan.. Untuk perhitungannya dapat dirumuskan sebagai berikut:

$$
v_{(x)}=\sum_{i=1}^{n} w_{j} x_{i j}
$$

$\mathrm{X}=$ objek/alternatif

$\mathrm{Vi}=$ Nilai keseluruhan dari alternatif pilihan suatu kriteria.

$\mathrm{Wj}=$ bobot prioritas subkriteria

$\mathrm{Xij}=$ Nilai alternatif pilihan kriteria.

\section{Metode Pengerjaan}

Untuk mempermudah dalam penulisan skripsi ini penentuan metode adalah hal yang sangat penting. Metode merupakan langkah - langkah sistematis yang digunakan untuk mempermudah dalam pembuatan sistem aplikasi pengolahan data manajemen aset. Metode yang digunakan pada penelitian ini adalah SDLC yang mengacu pada gambar 2.1. Namun, pada metode pengerjaan dalam penelitian ini tahap pemeliharaan tidak digunakan. Adapun metode pengerjaan yang digunakan dapat dijelaskan sebagai berikut :

\section{a. Tahap Perencanaan}

Tahap ini dilakukan untuk mendeskripsikan batasan dan ruang lingkup aplikasi serta sudut pandang user yang utama. Mempelajari konsep sistem dan permasalahan yang hendak diselesaikan. Apakah sistem baru tersebut realistis dalam masalah pembiayaan, waktu, serta perbedaan dengan sistem yang ada sekarang.

\section{b. Tahap Analisa}

Tahap ini dilakukan untuk pengumpulan data secara lengkap kemudian di analisis dan didefinisikan. Fase ini harus dikerjakan secara lengkap untuk bisa menghasilkan desain yang bagus dan lengkap. Tahap analisis ini mencakup :

1. Analisis terhadap sistem berjalan 
Tahap ini dilakukan untuk mengevaluasi dan menetukan permasalahan yang dihadapi. Hal ini bertujuan agar analisis tersebut dapat diketahui permasalahannya dan untuk mengetahui kelemahan yang ada pada sistem yang baru. Oleh sebab itu diperlukan pengumpulan data yang diperlukan untuk mendukung pembuatan sistem mendukung pembuatan sistem pengumpulan data adalah proses awal dalam pencarian data yang diperlukan untuk mendukung penelitian ini, serta melihat apa yang dibutuhkan demi tercapainya hasil yang diinginkan. Teknik pengumpulan data yang dilakukan adalah sebagai berikut :

a. Observasi

Teknik observasi dilakukan untuk memperoleh data dengan cara mengamati terhadap sistem kerja yang sedang berjalan baik secara langsung maupun tidak langsung di lingkungan kantor Bappeda Provinsi Riau.

b. Wawancara

Pengumpulan data dengan wawancara ini dilakukan untuk mencari data dan informasi tentang hal-hal yang dibutuhkan dalam penelitian. Wawancara dilakukan dengan bagian yang dijadikan objek penelitian. Dalam hal ini dilakukan dengan pihak yang terkait yaitu bagian pengelola aset atau inventaris Kantor BAPPEDA Provinsi Riau. Wawancara ini mefokuskan bagaimana Menentukan Nilai Penyusutan aset atau inventaris dan bagaimana pengontrolan aset atau inventaris dalam setiap periode sehingga tidak menimbulkan kerugian pada negara dan kinerja petugas pada Kantor BAPPEDA Provinsi Riau. 3.

\section{c. Studi Literatur}

Pengumpulan data yang dilakukan dengan cara mempelajari dan meneliti berbagai literature dari perpustakaan yang bersumber dari buku-buku, jurnal ilmiah, situs internet, dan bacaan lainya yang berkaitan dengan penelitian yang dilakukan. Tahap ini dilakukan untuk meneliti referensi materi terkait dengan pembahasan yang berkaitan dengan analisa dan perancangan perangkat lunak atau sistem serta konsep yang diterapkan dalam perancangan perangkat lunak atau sistem baik pada situs yang dipercaya maupun pada buku-buku yang resmi.

\section{Analisis sistem informasi}

Penelitian sistem yang ada dengan target merancang sistem yang baru, dan dapat diperbaharui.

\section{c. Tahap Rancangan}

Tahap ini merupakan tahap perancangan yang dilakukan setelah analisa kebutuhan selesai dikumpulkan secara lengkap. Pada tahap ini, sistem analis berkonsentrasi pada bagaimana sistem dibangun dengan memperhatikan langkah -langkah berikut :

1. Mendefinisikan tujuan sistem, tidak hanya berdasarkan informasi dari user, tetapi juga berupa analisa dari abstraksi dan karakteristik keseluruhan kebutuhan informasi Sistem.

2. Membangun model konseptual, berupa gambaran sistem secara keseluruhanyang menggambarkan satuan fungsional sebagai unit sistem.

3. Menerapkan kendala-kendala organisasi

4. Mendefinisikan aktifitas pemrosesan data

5. Menyiapkan proposalsistem desain.

\section{d. Tahap Implementasi}

Pada tahap ini dilakukan implementasi sistem dan pengkajian kembali kelayakan dari sistem yang telah dirancang, apakah sistem tersebut sudah 
sesuai atau masih perlu dilakukan peninjauan kembali atau penyempurnaan. Pengujian adalah Fase yang melibatkan pengujian sekumpulan modul yang telah di integrasikan menjadi sebuah sistem. Masalah yang paling umum yang muncul pada sistem perangkat lunak besar adalah ketidaksesuaian interface. Proses pengujian subsistem dengan demikian harus terkonsentrasi pada deteksi kesalahan interface modul dengan menjalankan interface ini berkali-kali.

\section{Hasil dan Pembahasan}

\section{a. Analisa Sistem}

Secara umum fungsi dari Aplikasi pengelolaan Inventaris ini adalah semua data-data inventaris di setiap ruangan yang ada di BAPPEDA Provinsi Riau, baik data yang masuk ke inventaris maupun data yang akan dikeluarkan serta membuat laporan inventaris tiap ruangan. Aplikasi pengelolaan inventaris ini digunakan oleh Staff Bagian Perlengkapan yang diperuntukkan untuk mengelola data inventaris dan membuat laporan inventaris dari tiap ruangan. fungsi utama dari aplikasi pengelolaan inventaris ini adalah sebagai berikut :

1. Authentication (Login Staff Bagian Perlengkapan)

2. Pengolahan Data Ruangan oleh Staff Bagian Perlengkapan
a. Menambah data ruangan
b. Edit data ruangan
c. Menghapus data ruangan
d. Mencari data ruangan

3. Pengelolaan Data Inventaris Oleh Staff Bagian Perlengkapan

a. Menambah data inventaris

b. Edit data inventaris

c. Menghapus data inventaris

4. Melakukan Proses Metode Straigt Line dalam menentukan nilai penyusutan aset
5. Melakukan Proses Metode Multi Attribute Utility Theory dalam melakukan perhitungan nilai aset dan prioritas penghapusan data asset

6. Pembuatan laporan inventaris

\section{b. Data Penelitian}

Data penelitian adalah sesuatu hal yang sangat penting dalam melakukan sebuh penelitian yang dapat menghasilkan suatu informasi yang baik, maka diperlukan juga data-data yang baik, karena pada dasarnya merupakan hasil dari pengolahan data yang diinput pada sistem. Dalam sistem pengolahan data iventaris dan aset BAPPEDA Provinsi Riau data dapat digolongkan menjadi 2 (dua) bagian: yaitu data internal dan data eksternal.

\section{c. Pemodelan Kriteria}

Menentukan kriteria adalah bagian yang sangat penting dalam melakukan pengolahan data manajemen asset dengan menggunakan metode Straight Line dan seleksi penghapusan aset dengan menggunakan metode Multi Attribute Utility Theory (Maut).

Table 1 kriteria

\begin{tabular}{|c|l|}
\hline Kritenia & \multicolumn{1}{|c|}{ Keterangan } \\
\hline $\mathrm{C} 1$ & Nilai Buku \\
\hline $\mathrm{C} 2$ & Kondisi Fisik Iventaris / Aset \\
\hline $\mathrm{C} 3$ & Manfaat / Fungsi \\
\hline $\mathrm{C} 4$ & Produk Dalam Negen / Luar Negen \\
\hline $\mathrm{C} 5$ & Ketersediaan Barang Pengganti \\
\hline
\end{tabular}

\section{d. Pemodelan Sistem}

Pemodelan sistem diharapkan dapat memberikan kemudahankemudahan 
dalam melakukan proses dalam pemodelan sistem yang baru yang dapat menggambarkan sistem yang akan dibangun mulai dari Contex diagram , Data Flow Diagram dan ERD.

Context Diagram merupakan gambaran sistem secara umum yang memperlihatkan hubungan antara entityentity serta aliran informasi dalam sebuah sistem yang digambarkan secara logika.

Gambaran ini juga memperlihatkan hubungan antara input dan output sistem dengan dunia luar tempat sistem tersebut ditempatkan, seluruh proses yang terjadi dalam sistem diwakili oleh satu proses saja. Keuntungan dalam menggunakan Context Diagram memudahkan untuk memahami sistem yang dikembangkan.

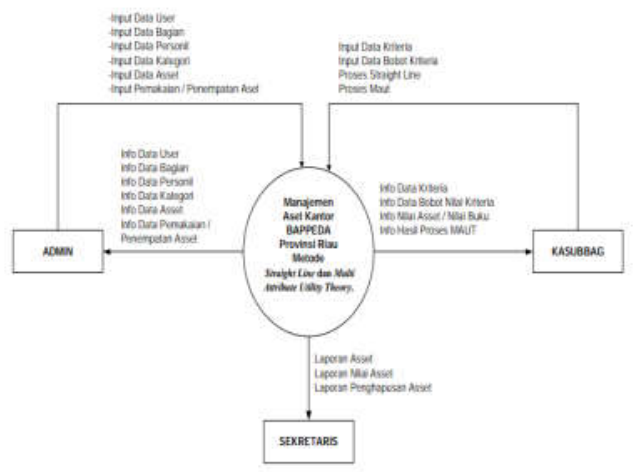

Gambar 1. Context Diagram

\section{IMPLEMENTASI}

Hasil dari pembuatan sistem yang telah dirancang dan dibuat coding dapat dilihat halaman implementasi mulai dari halaman penginputan data, proses menghitung nilai buku, proses penghapusan aset dan laporan dapat dilihat pada gambar implemenetasi sistem di bawah ini.

\section{a. Implementasi Form Login}

Implementasi halaman login adalah halaman untuk memasuki aplikasi oleh pengguna dengan memasukan user login dan password yang akan di verifikasi oleh sistem.

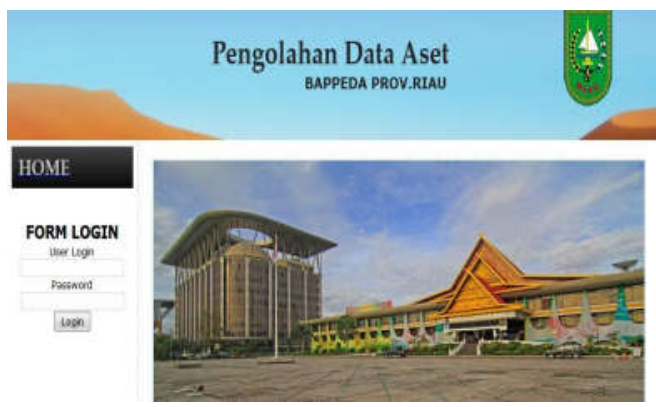

Gambar 2. Implementasi Form Login

\section{b.Implementasi Halaman Admin}

Implementasi halaman admin adalah halaman yang diberikan akses untuk menginput data user, pegawai, ruangan, aset, pemakain aset, penempatan aset sesuai dengan ruangan atau bagian. Adapun hasil implementasi halaman admin dapat di lihat pada gambar di bawah ini.

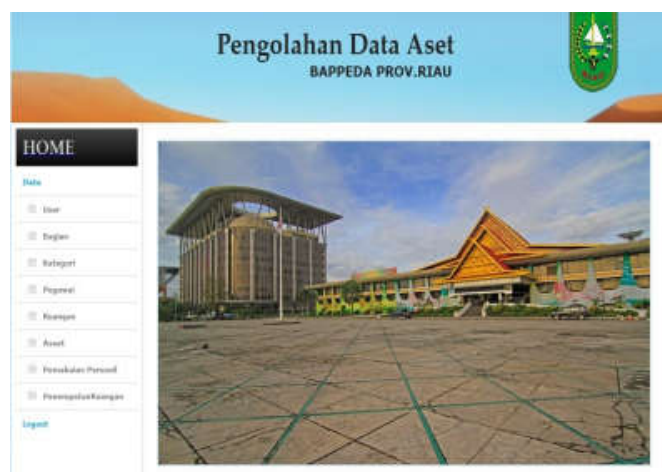

Gambar 3. Implementasi Halaman Admin

\section{c. Implementasi Proses Stragiht Line}

Implementasi proses straight line adalah untuk melakukan proses untuk mendapatkan nilai buku, penyusutan aset dan nilai buku yang habis atau negative 
akan dilakukan proses SPK dengan metode MAUT untuk mengetahui urutan penghapusan aset sesuai dengan penjelasan perhitungan secara manual penyusutan dengan metode Straight Line untuk mendapatkan nilai buku atau penyusutan asset. Hasil proses Stragiht Line dapat dilihat pada gambar berikut.

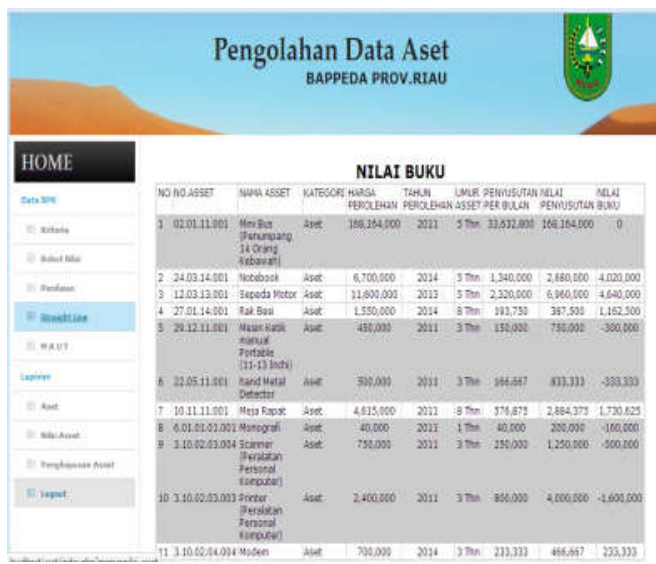

Gambar 4.Implementasi Proses Straight

Line

\section{d. Implementasi SPK Metode MAUT}

Proses SPK dengan metode MAUT adalah digunakan untuk melakukan perangkingan nilai kelayakan penghapusan aset, semua aset yang memiliki nilai buku lebih kecil atau sama dengan 0 (nol) maka akan di proses oleh MAUT untuk melakukan penghapusan aset pada tahun yang akan datang.

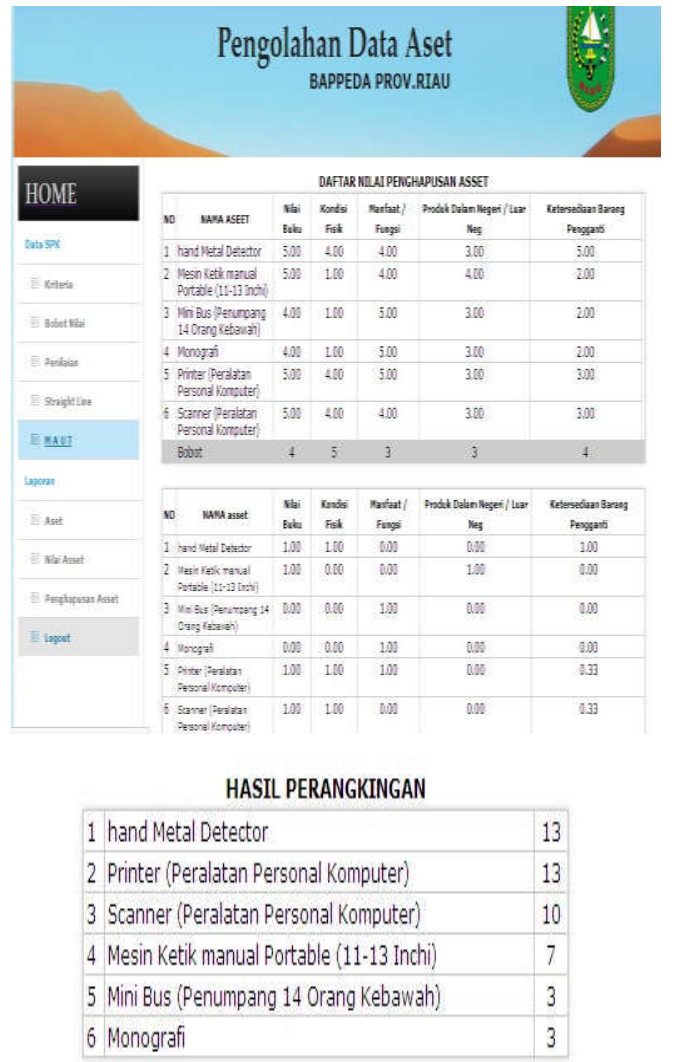

Gambar 5. Implementasi Proses SPK Metode MAUT

\section{PENUTUP}

\section{a. Kesimpulan}

Kesimpulan dari penelitian yang dilakukan dalam membangun sebuah sistem Pengolahan Data Manajemen Aset Kantor Bappeda Provinsi Riau dengan metode Straight Line dan Multi Attribute Utility Theory.

1. Dengan adanya sistem ini dapat membantu dalam menentukan penyusutan aset, nilai aset dan penghapusan aset.

2. Dapat membantu dalam mewujudkan tertib administrasi pengelolaan aset, tertib dokumen aset berkaitan dengan upaya penyediaan dan pendataan data-data atau dokumen yang 
menyertai keberadaan aset, sedangkan tertib administrasi lebih dimaksudkan pada upaya membangun prosedur pengelolaan aset mulai saat pengadaan.

\section{b. Saran}

Untuk dapat sistem ini berjalan sesuai dengan tujuan yang di kehendaki ada beberapa saran dari penulis.

1. Peningkatan Sumber Daya Manusia dilakukan dengan cara training atau pelatihan terhadap sistem yang akan dipakai, terutama bagi admin atau operator komputer yang menggunakan sistem.

2. Selalu melakukan perubahan atau pengembangan terhadap sistem sesuai dengan perkembangan zaman dan kebutuhan yang diinginkan.

\section{DAFTAR PUSTAKA}

Anhar. 2010. PHP \& MySql Secara Otodidak. Jakarta: PT TransMedia.

Al Fatta, Hanif. 2007. Analisis dan Perancangan Sistem Informasi. Yogyakarta: ANDI.

A.S Rosa dan Salahuddin M, 2011. Modul Pembelajaran Rekayasa Perangkat Lunak (Terstruktur dan Berorientasi Objek), Bandung: Modula.

Departemen Dalam Negeri (2007). Peraturan Menteri Dalam Negeri Republik Indonesia Nomor 17 tahun 2007 tentang pedoman teknis pengelolaan barang milik daerah. Jakarta.

Diar Puji Oktavian (2010) PHP\& MySQL Dengan Editor Dreamweaver MX, Yogyakarta: Andi.
Earl K. Stice, James D. Stice dan K. Fred Skousen. Penerjemah: Aria Farahmita, SE.Ak, Amanugrahani, SE.Ak, Taufik Hendrawan, SE.Ak .2005 .

Akuntansi Intermediate. Edisi 15. Jakarta: Salemba Empat.

Jogiyanto, 2003, Analisa dan Desain Sistem Informasi, Yogyakarta: ANDI.

Kadir, Abdul. 2003. Pemograman Web Mencakup: HTML, CSS, JAVASCRIPT dan PHP. Yogyakarta: ANDI.

Keputusan Menteri Keuangan Republik Indonesia Nomor 94/KM.6/2013 tentang modul penyusutan barang milik negara berupa aset tetap pada entitas pemerintah pusat.

Kristanto Andri, 2003, Perancangan Sistem Informasi dan Aplikasinya, Yogyakarta: Gava Media.

Peraturan Menteri Dalam Negeri Republik Indonesia No. 17 Tahun 2007 tentang Pedoman Teknis Pengelolaan Barang Milik Daerah, Jakarta.

Schein, Edgar H, 2008, Organizational Culture and Leadership, Third

Edition, Jossey -Bass Publishers, San Francisco.

Suhairi, Perancangan Sistem Informasi Manajemen Aset, Universitas Gunadarma.

Terry, George R. dan Rue, Leslie W. 2005. Dasar - Dasar Manajemen. Jakarta: Bumi Aksara. 
Wijayanti, Irine Diana Sari. 2008.

Manajemen. Editor: Ari

Setiawan.Yogyakarta: Mitra

Cendikia. 